Volume 12

Issue 2 Images And Collective Violence:

Function, Use And Memory

Article 8

$10-2018$

\title{
El Mocito: A Study of Cruelty at the Intersection of Chile's Military and Civil Society
}

Ana Laura Ros

Binghamton University

Follow this and additional works at: https://digitalcommons.usf.edu/gsp

\section{Recommended Citation}

Ros, Ana Laura (2018) "El Mocito: A Study of Cruelty at the Intersection of Chile's Military and Civil Society," Genocide Studies and Prevention: An International Journal: Vol. 12: Iss. 2: 107-124.

DOI:

https://doi.org/10.5038/1911-9933.12.2.1524

Available at: https://digitalcommons.usf.edu/gsp/vol12/iss2/8

This Articles is brought to you for free and open access by the Open Access Journals at Digital Commons @ University of South Florida. It has been accepted for inclusion in Genocide Studies and Prevention: An International Journal by an authorized editor of Digital Commons @ University of South Florida. For more information, please contact digitalcommons@usf.edu. 


\section{El Mocito: A Study of Cruelty at the Intersection of Chile's Military and Civil}

Society

\section{Acknowledgements}

This article was translated into English by Edith J. Adams. 


\title{
EI Mocito: A Study of Cruelty at the Intersection of Chile's Military and Civil Society
}

\author{
Ana Laura Ros \\ Binghamton University \\ Binghamton, New York, USA
}

\section{Introduction $^{1}$}

The more time that passes since the fall of the last military regimes in Latin America's Southern Cone, the more public expectation of moving beyond the transition period and toward democratic consolidation grows. This consolidation can only begin to develop when social actors transform themselves into "active partners" of democracy, as Mayoraga affirms. ${ }^{2}$ In the case of the Armed Forces, this transformation presumes accepting a subordinate role to civilian governments and recognizing democracy as the only possible political system. According to Narcís Serra, a specialist on the subject, democratic consolidation begins after the elimination of military interference in governmental and judicial tasks, a process typical of the transition phase. Civilian leaders then assume the work of establishing a new defense policy, guaranteeing its implementation, and directing all activities of the Armed Forces. ${ }^{3}$ In practice, however, this process is filled with challenges, as it necessarily implies carrying out changes to profoundly established structures, such as the institutional character of the Armed Forces, and its relationships with the civilian government and the population. As a result, in many countries, some aspects of the transition phase are prolonged, coinciding with important steps in the process toward democratic consolidation, thus causing confusion and frustration within the society.

Twenty-five years after the end of the Chilean military dictatorship (1973-1990), the redemocratization process still has not drawn to a close. Although strides have been made to subordinate the Armed Forces to civilian governments and the needs of the current society, vestiges of the dictatorship era and authoritarian enclaves still exist and impede democratic consolidation. These tensions in civil-military relations have sparked the concern of national and international human rights organizations and a large portion of Chilean society to such a degree that they have even begun to occupy a space in the country's cultural production. In recent years, various films have been released that reflect upon how the military and the civil society affect one another, particularly in relation to crucial subjects, such as the production of cruelty. Examples of these films are: El soldado que no fue/The Soldier That Was Not ${ }^{4}$, El mocito/The Young Butler ${ }^{5}$, El tio/The Uncle ${ }^{6}$, and La odisea de Ulises/Ulysses's Odyssey. ${ }^{7}$

Although my forthcoming book will offer a comparative analysis of these works, in this article I will focus on the film that has had both the biggest impact and generated the greatest response in different formats and outlets, including academic articles, journalistic notes, blog entries, and radio and television interviews with the directors and with the protagonist. ${ }^{8}$ The film, El mocito, tackles

\footnotetext{
${ }^{1}$ Since this article was submitted, important developments occurred in the field of civil-military relations in Chile. These are some of the most relevant events: in 2016, the parliament passed law 20.968, proposed by President Bachelet, which defines torture as a crime and excludes civilians from military courts, both as plaintiffs and as defendants. Also, in 2017, President Bachelet drafted a bill to compensate 27,952 prison survivors with a one-time payment of 3 million Chilean pesos (surviving spouses would receive $60 \%$ of the amount). Finally, in 2017, a new bill was drafted to eliminate the Amnesty Law from the constitution, even though judges had stopped invoking it after 2006 when the ICHR requested its repeal.

${ }^{2}$ René Antonio Mayoraga, “Las perspectivas de consolidación de la democracia y los problemas delas relaciones institucionales cívico-militares," in La cuestión militar en cuestión. Democracia y Fuerzas Armadas, ed. Raúl Barrios Morón and Rene Antonio Mayoraga (La Paz: Centro Boliviano de Estudios Interdisciplinarios, 1994), 55.

${ }^{3}$ Narcís Serra, The Military Transition: Democratic Reform of the Armed Forces (New York: Cambridge University Press, 2010), 28.

${ }^{4}$ Leopoldo Gutiérrez, El soldado que no fue (Santiago de Chile: Polo Comunications, 2010).

${ }^{5}$ Marcela Said and Jean de Certeau, El mocito (Santiago de Chile: Icalmafilms, 2011), DVD.

${ }^{6}$ Mateo Iribarren, El Tío (Santiago de Chile: Monkey Puzzle Media, 2013), DVD.

${ }^{7}$ Lorena Manríquez and Miguel Picker, La odisea de Ulises (Los Angeles: Andes Media LLC, 2014), DVD.

${ }^{8}$ In addition to the article by Eva Usi and the two articles by Michael Lazzara cited in this work, the film has been addressed in many publications, including those by José Parra, Jorge Morales, Jara Villalobos, Camila Gutiérrez, Lucía
} 
Chile's dictatorial past through the perspective of a civilian who was closely connected to the Armed Forces. In contrast to earlier journalistic works about the dictatorship, which concentrated on well-known official perpetrators and/or repressive actions, ${ }^{9}$ this documentary focuses on an ambiguous actor, and, by doing so, shines a light on grey areas of the regime and the civil society. El mocito addresses the case of an individual living on the border between worlds often perceived as mutually exclusive. He is a civilian, but he was also a member of the DINA-Chile's secret police under Pinochet - though not as a member of the Armed Forces, but rather in the role of a butler. Although, as far as the public knows, he never participated in torture or assassinations, through this position, he was aware of what was taking place, bore witness to events related to state repression, and by fulfilling the tasks of his work, in many ways sustained the framework of the authoritarian system.

By focusing on an atypical actor who is simultaneously an outsider and an insider in both the Armed Forces and the civil society, the documentary presents a unique perspective on these two groups and their intersections. In so doing, the film poses questions about responsibility for, and complicity with, the cruelty that took place during the military regime and beyond that all members of Chilean society must consider. How far can we extend responsibility for what happened? How do we measure the guilt or innocence of those who did not commit or order the perpetration of crimes, but were nevertheless part of the system that condoned such acts? Can victims exist within the group typically thought of as victimizers? What forms does cruelty take in civil society in nonauthoritarian contexts? These queries imply a questioning of the military institution in its present form and challenge both the concept of the citizen shaped within democracy and the possibilities of nunca más/never again ${ }^{10}$ in Chile today. They are questions that the filmmakers leave unanswered with the intent, perhaps, of allowing them to be explored in other realms, such as political and educational spaces where they can be debated and may eventually generate potential solutions.

Before beginning to discuss the documentary, I will first offer a brief reflection on the latest developments in Chile's redemocratization process, which, as I propose, inform and drive the type of documentary production with which films such as El mocito are associated. The theoretical framework that will inform my analysis of the film is rooted primarily in the work of Zygmunt Bauman (particularly his reflections on Milgram and Zimbardo's experiments) and Hannah Arendt, with important contributions from Daniel Feierstein on the sociology of genocide at the regional level.

Civil-Military Relations in Chile: Significant Gains and Unsettled Accounts in the Redemocratization Process

As civil-military relations expert Narcís Serra has noted, the redemocratization of a nation depends upon the success of its leaders in transforming the Armed Forces, a highly autonomous and politically powerful institution, into a state actor lacking powers of deliberation, one that faithfully executes the government's policies in order to ensure democracy.$^{11}$ This process proves challenging for both civil and military groups, given that they must adopt new roles and new forms of interacting while avoiding direct conflict. ${ }^{12}$ As previously mentioned, in the twenty-five years that have passed since the fall of the Chilean military regime, important gains have been made; however, unsettled accounts and authoritarian enclaves, both of which are incompatible with democratic order, persist

\footnotetext{
Quaretti and Olga Larrazaba.

${ }^{9}$ For example: Nancy Guzmán, Romo, confesiones de un torturador (Santiago: Editorial Planeta, 2000); Patricia Verdugo, Caso Arellano: Los zarpazos del puma (Santiago: CESOC Ediciones, 1989); Pruebas a la vista: La caravana de la muerte (Santiago: Sudamericana, 2000); Patricia Verdugo and Sebastian Brett, De la tortura no se habla: Agüero versus Meneses (Santiago: Catalonia, 2004).

10 A motto used by relatives of disappeared prisoners and human rights activists to express the need for truth, justice, and remembering in order to ensure that another coup d'état never occurs in Chile.

${ }^{11}$ Serra, The Military Transition, 26.

${ }^{12}$ For a detailed reflection on the long process of democratization in Chile, see Ana Ros, "Los otros con armas: Las complejas relaciones cívico-militares en el Chile de postdictadura," A Contracorriente. Revista de historia social y literatura de América Latina, 14, no. 2 (2017), 17-42, https://acontracorriente.chass.ncsu.edu/index.php/acontracorriente/ article/view/1560.
} 
in Chile and have caused alarm among various international groups such as The United Nations (UN), The Inter-American Court of Human Rights (IACHR), and Amnesty International. I will now discuss some of the most troubling examples. However, the significance of these gains and unsettled accounts can only be fully grasped in relation to the challenges faced by the governments that succeeded the military regime.

As Felipe Aguero ${ }^{13}$ affirms, in contrast to neighboring countries, where the end of the regime was preceded by a gradual opening to democracy or by a negotiation between the army and the opposition, the democratic transition in Chile followed the terms established in the 1980 Constitution, as proposed and approved by the military regime. Neither side, however, was satisfied with the implementation of these terms, which was mainly determined by the results of the 1988 plebiscite. While the regime had to accept that Pinochet could not rule the country again until 1997, the opposition had to move forward with the democratic elections enabled by the plebiscite, and in order to not place the redemocratization ${ }^{14}$ process at risk, they could not attempt to negotiate the validity of the documents produced under the regime. As a result, the first elected governments had to deal with a highly independent and influential Armed Forces built on prerogatives that were derived directly from preexisting official documents: the 1978 Amnesty Law, the 1980 Constitution, and the 1989 Organic Military Law. ${ }^{15}$

The Organic Military Law allowed the army to remain in control of its resources, which was crucial for preserving autonomy from, and supremacy over, the civilian government. It established that the army's budget could never be lower than it was in 1989, and it validated the Reserved Copper Law. According to this law, the Armed Forces received $10 \%$ of the yearly revenues obtained by CODELCO, the state-owned copper exportation company, for maintenance and weapons acquisition, with a minimum income of 180 millions dollars. ${ }^{16}$

Similarly, the 1980 Constitution granted the Armed Forces an active role in political life. It designated former dictator Augusto Pinochet as Chief Commander of the Armed Forces until 1998, thus eliminating the President's ability to dismiss military leaders. It also created the COSENA, or Counsel of National Security, an institution formed mainly by members of the Armed Forces and the police that possessed veto power over the Legislative, Judicial, and Executive branches, and was responsible for advising the President on subjects related to national security. Moreover, this constitution established the incorporation of Pinochet to the Senate after the end of his term as Commander, in Chief in 1998, and until the end of his life, thereby creating designated lifelong senators. As a result of this arrangement, nine of the thirty-eight members of the Senate were not elected democratically, but rather were nominated by the COSENA, the Supreme Court, and the President.

The Amnesty Law extended the Armed Forces' impunity by giving them the power to pardon regular and political crimes that occurred between the 1973 coup and 1978, which was the cruelest repressive period for all involved (perpetrators, accomplices, accessories to crimes). Therefore, many tribunals, predominantly in agreement with the regime, have declared themselves unable to judge human rights violations, thereby transferring the cases to military courts.

\footnotetext{
${ }^{13}$ Aguero, Felipe, “Treinta años después. La ciencia política y las relaciones Fuerzas Armadas, Estado y Sociedad," Revista de Cienca Política, 23, no. 2 (2003), 251-272.

${ }^{14}$ This risk was mainly linked to conflicts generated by the possibility of prosecuting the human rights violations and investigating the Pinochet family's illicit gains. The constant tension between the army and civil politicians materialized in two episodes that conveyed the threat of a new coup, respectively known as "el día del enlace" and "el boinazo," For more information on this subject, see Steve Stern, Reckoning with Pinochet (Durham \& London: Duke University Press, 2010).

${ }^{15}$ David Álvarez Veloso, "Fuerzas Armadas en Chile: entre la configuración de nuevos roles y la normalización de las relaciones cívico-militares," Red de Bibliotecas Virtuales de Ciencias Sociales de América Latina y el Caribe, accessed May 6, 2016, http://bibliotecavirtual.clacso.org.ar/ar/libros/becas/2003/mili/alvarez.pdf.

${ }^{16}$ Cristina Florina Matei and Marcos Robledo, "Democratic Civilan Control and Military Effectiveness in Chile," in The Routledge Handbook of Civic-Military Relations, ed. Florina Cristiana Matei and Thomas Bruneau, (New York: Routledge, 2013), 284.
} 
Moreover, the post-dictatorship governments inherited systems that extended military control and outlook in civic society. Under the regime, the police force, Carabineros, was part of the Defense Cabinet, participated actively in the repressive system, and had their crimes judged by military courts. Similarly, during the regime, the Mandatory Military Service became longer, harder to elude, and more abusive than ever before.

Since the end of the dictatorship, most presidents have worked to gradually achieve truth and justice, as well as to gain civilian control over the Armed Forces, especially once Pinochet, as lifelong senator, was detained in London for his crimes against humanity. For instance, very early on, Presidents Patricio Alwyn (1990-1994) and Eduardo Frei-Tagle (1994-2000) rejected the promotion of officers who had been accused of repressive actions and fraud; they also increased presidential power over military appointments, dismissals and transfers. Moreover, Frei's Secretary of Justice, Soledad Avelar, implemented a reform in the Supreme Court that brought an end to Pinochet's hegemony. In the same vein, President Ricardo Lagos (2000-2006) limited the COSENA's power. Each of these elected leaders also worked to reveal the truth about human rights abuses by the military in order to promote justice, as evidenced by the Rettig Report (1991), the "table of dialogue" (1999), and the Valech Report (2004).

Additionally, many places of memory were created during this period, including the Museum of Memory, which was inaugurated by President Michelle Bachelet (2006-2010, 2014-2018) and has become internationally renowned. President Bachelet continued her predecessor's work to redefine the role of the Armed Forces and make it a matter accessible to the community. She played a crucial role in strengthening the civilian presence in the Department of Defense and in restructuring the Department of Internal Affairs in order to make it more effective and include police institutions. During her administration and that of President Sebastian Piñera (2010-1014), official institutes and commissions were also created to handle and prevent human rights violations, including the Department of Justice's Human Rights Under-secretariat and the Parliament's Commission of Human Rights, Nationality, and Citizenship.

Despite this substantial progress toward a consolidated democracy, however, the Armed Forces still maintain certain privileges that raise questions about their expected subordination to civilian governments and their service to the democratic organization of civil society. For example, the army continues to control its budget and secure its resources through the Restricted Law on Copper. Likewise, the Amnesty Law of 1978 remains valid, despite the fact that forms of evading its effects have been discovered (for example, by interpreting disappearances as permanent kidnappings, the crime is legally still active and thus can be brought to trial). As for prosecutions, although various agents of state repression are serving criminal sentences, the majority of those convicted carry out these sentences in exclusive prisons, and the number of convicted agents is much lower than those who walk free. According to official statistics released at the end of 2015, of the 3,000 -5,000 perpetrators of violent crimes who worked in the DINA and the CNI - the Centro Nacional de Informaciones, DINA's new name after 1977- only 495 have been processed and only 163 are currently serving prison sentences.

The country's dictatorial past continues to live on in other ways, including, for example, the fact that the army still possesses the power to destroy records without prior approval from the Executive Branch. ${ }^{17}$ Additionally, those who worked for the DINA/CNI can continue to offer their services to the country's military institutions. These military privileges sharply contrast with the lack of reparation and specialized attention given to the many victims of human rights abuses, ${ }_{1}^{18}$ as well as the continued prohibition of other individuals from returning to Chile after being forced into exile during the dictatorship. ${ }^{19}$

\footnotetext{
17 "Privilegios para militares presos mantienen impunidad en Chile," Sputnik News, April 8, 2015, accessed August 8, 2017, http://mundo.sputniknews.com/opinion/20150804/1039956389.html.

${ }^{18}$ Gonzalo Rodríguez Torres, “Los otros abuelos osos sobrevivientes de la dictadura pero olvidados e invisibilizados en democracia," Radio Villa Francia. Levantando la Voz, March 16, 2016, accessed August 8, 2017, http://www. radiovillafrancia.cl/los-otros-abuelos-osos-sobrevivientes-de-la-dictadura-pero-olvidados-e-invisibilizados-endemocracia.

19 “Comité Contra la Tortura ONU regresó para revisar comrpomisos y avances," Enlace Mapuche Internacional Noticias,
} 
With regard to defense, the advances that have been made still have not managed to fully eradicate all authoritarian enclaves. Certainly, there have been achievements: the role of the Armed Forces, for example, has been reoriented toward international affairs (including peace missions and fighting against regional organized crime); the civil leadership in the Ministry of Defense has been strengthened; and the country's police institutions, such as the Carabineros and the Investigative Police, have been subordinated to the newly restructured Ministry of the Interior and Public Security. Despite these gains, however, there is still a strong tendency toward militarization within the Chilean police force. Although the Carabineros are not a deliberative body, they rely upon paramilitary organizational structures and militaristic disciplinary codes, and their members have military training. Moreover, since its creation, the group has been linked to the use of unchecked violent repression on the Chilean population. These actions continue to be endorsed today through efforts such as the enforcement of Supreme Decree 1086, signed into law during the dictatorship, which requires authorization in order to stage a public protest. The Carabineros actions are also bolstered by the new preventative identity control law, which authorizes them to detain any individual, particularly in situations of protest, and request identification. Similarly, until recently Carabinero's crimes against civilians were treated as competence of military justice and thus avoided adequate punishment under the law, which strengthened their repressive tendencies.

A vestige of the dictatorship that has extended to the impunity of the Carabineros is the continual harassment of the inhabitants of Mapuche and the Araucanía region, which is one of the poorest areas in Chile. The state has justified the use of excessive amounts of repressive violence, as a response to what were interpreted as terrorist acts committed by members of the community. Confronted with acts of legitimate social protest, the government has applied Chile's antiterrorist law, which was enacted in 1984 when Pinochet's regime was faced with a wave of protests and select groups were endorsing armed actions. ${ }^{20}$

Following Contreras' assertion, the militarization of Mapuche forces us to consider other acts of protest that signal the neutralization of hotbeds of resistance, such as the government's management of youth, particularly those from low-income backgrounds, through compulsory military service. Although the structure of Chile's conscription program has undergone changes in its recruitment techniques and organization, both of which have encouraged voluntary participation, conscientious objection continues to be considered an insufficient excuse to exempt young people from participating, and the conscription period continues to be governed by the principles of obedience, hierarchy, and discipline that characterize the Armed Forces. As of 2015, in addition to the over 10,000 youths that enrolled annually in the Military Service, and those studying in the military academies, there were ten pre-military high schools in Chile, with a total of 2,000 students. $^{21}$

Finally, another extension of militarism in the post-dictatorship era is the inclusion of military imaginaries within the formal education system.22 For example, courses in school often include stories that emphasize the heroism of certain military figures, which participated in the construction of the nation. Students also come to see military intervention as both normal and unquestionable. For Contreras, this normalization is further promoted with

ceremonias en fechas memorables para el ejército, en donde los colegios detienen sus clases para celebrar las efemérides, vistiéndolos con ropa militar, incentivando la creación artística en torno a la fecha pero no generando instancias de reflexión que profundicen el cuestionamiento del belicismo.

April 4, 2016, accessed August 8, 2017, https://www.mapuche-nation.org/espanol/html/noticias/ntcs-562.html.

${ }^{20}$ Paula Molina, "Los problemas de Chile y su ley antiterrorista," BBC News, August 1, 2014, accessed August 8, 2017, http://www.bbc.com/mundo/noticias 2014/08/140801 chile ley antiterrorista nc.

21 "Colegios premilitares en Chile: El rigor de la disciplina," 24Horas.cl, accessed December 21, 2017, http://www.24horas. cl/nacional/colegios-premilitares-en-chile-el-rigor-de-la-disciplina-1671628.

${ }^{22}$ Dan Contreras, "La violencia, el servicio military y el sistema educativo en Chile," War Resisters International, May 17, 2014, accessed August 8, 2017, http://www.wri-irg.org/en/node/23364. 
["ceremonies on memorable days for the army, in which schools cancel classes to celebrate these holidays, dressing the children in military clothing, incentivizing artistic creation related to the celebration, but never allowing space for reflective moments in which students can consider and question the day's militarism. ${ }^{23}$ ]

Likewise, Chile has maintained certain practices during the school day that were born in military barracks and have come to be normalized among the civilian population: pseudo-military brigades that help to maintain order on the playground, bands that perform military music, uniforms, and protocols of order that are very similar to those used in military schools. ${ }^{24}$

\section{El Mocito: The Blurred Line Between Civilians and the Military in the Production of Cruelty}

As mentioned before, of all the documentaries that tackle civil-military relations in Chile, El mocito, directed by Marcela Said and Jean de Certeau, has had the greatest impact across an array of disciplines, including journalism and academia, ultimately becoming what Michael Lazzara ${ }^{25}$ has called a "phenomenon." ${ }^{26}$ The "mocito phenomenon" can be attributed to the centrality of the film's protagonist, Jorgelino Vergara, in the lawsuits associated with the crimes against humanity committed during the dictatorship. In 2007, after years of living in relative isolation, Vergara was located and called to testify about his involvement in the DINA during the 1970s. Eager to prove his innocence in the face of murder accusations, Vergara offered a detailed account of his knowledge of those years of maximum repressive violence, revealing "uno de los secretos mejor guardados de la dictadura" ["one of the best kept secrets of the dictatorship"] ${ }^{27}$ His narrative of the events helped to confirm the existence of the Simón Bolívar extermination center and the Lautaro Brigade, a group of DINA agents who operated in the center. In his testimony, Vergara identified more than seventy ex-agents who had never before been associated with acts of state-sponsored terrorism, a move that led to the largest prosecution of human rights violations in the country's history. Vergara's detailed memories helped to illuminate some of the most inhumane forms of repression employed during the regime and reveal the circumstances surrounding the deaths of many of the desaparecidos.

However, Vergara remained a privileged actor at his detention and was exempted from the accusations that brought him before the court and drove him to testify in the first place. According to his own words and those of other suspects, Vergara never participated directly in kidnappings, torture sessions, or assassinations during his time at Simón Bolívar, but rather provided assistance in his role as butler when he was just an adolescent. It is there, perhaps, that we can derive the meaning of the word "mocito" ("youngster" or "young butler") that appears in the documentary's title: an indication of both Vergara's youth and occupation. When he was seventeen years old, and after having worked as a servant for a military family, for two years, Vergara received fast training and joined the DINA. However, he belonged to the lowest levels of the organization: serving

\footnotetext{
${ }^{23}$ Ibid.

${ }^{24}$ Ibid.

${ }^{25}$ Michael Lazzara, "El fenómeno Mocito (Las puestas en escena de un sujeto cómplice)", A Contracorriente. Una revista de historia social y literatura de América Latina, 12, no. 1 (2014), 21, accessed August 8, 2017, https://acontracorriente.chass. ncsu.edu/index.php/acontracorriente/article/view/1301.

${ }^{26}$ In a more recent article, "Complicity and Responsibility in the Aftermath of the Pinochet Regime: The Case of $E l$ Mocito," Lazzara offers additional information about the use of the documentary in educational settings. His work suggests that the films themselves are not mere vehicles of collective memory, but rather that the memory project arises as a result of what is done with these works. In other words, the interpretation and the use of that interpretation in both educational and political settings is what gives shape to the memory of Chile's dictatorial past while also delineating the needs of the present.

${ }^{27}$ Javier Rebolledo, author of A la sombra de los cuervos: los cómplices civiles de la dictadura (Santiago: Ceibo Ediciones, 2012), worked as a researcher and assistant director on Said and de Certeau's documentary. After five years of conducting research and thirty hours of interviewing Vergara for the film, Rebolledo embarked on his own project entitled La danza de los cuervos/The Dance of the Ravens (Santiago: Editorial Planeta, 2016), a detailed piece of investigative journalism that delves into Vergara's life as a mocito, his participation in the DINA, and his destiny upon being discharged from Simón Bolívar in 1985. Rebolledo's study was praised by critics and was the best-selling non-fiction book in Chile for five consecutive weeks.
} 
coffee to the main agents during torture sessions, delivering food to the prisoners, watching over them during their trips to the bathroom, standing guard and cleaning away any evidence of the exterminations taking place at the center, and even transporting bodies to the trunks of cars that would disappear the victims for good. This ambivalent position of the protagonist with respect to the crimes committed by the DINA raises a crucial dilemma regarding his possible guilt or innocence. The same quandary is presented at the beginning of the documentary when, in a modest house in Nuñoa, looking at the camera, Vergara states:

Yo soy el hombre más honesto que ha pisado la tierra. Aunque tú no lo creas. Aunque fui partícipe de asesinatos, secuestros y todo el atado... Oye, yo lo vi, pero nada más... O sea, yo no participé. O sea, tu no podrías acusarme a mí de asesino... ¿Si o no? Porque de hecho, en los hechos, yo no fui asesino. Pero sí te digo una cosa: asesinaron, mataron tanta gente, comadre.... Mira, mira... ¡Sin escrúpulos las mataron! Pa'que te digo más: las mataron tan sin escrúpulos que a mí me dolía siendo un adolescente, pues. Ese es mi cuento.

[I am the most honest man who has walked this Earth. Even though you don't believe me. Even though I participated in assassinations, kidnappings, and all of that... Listen, I saw it, but nothing more... I mean, I didn't participate. Or rather, you wouldn't be able to accuse me of being a murderer... Yes or no? Because in fact, if you look at the facts, I wasn't a murderer. But I will tell you something: they assassinated, killed so many people, man... Look, look... They killed them without shame! And I'll tell ya something else: they killed them so shamelessly that it hurt me as a teenager, ya know? That's my story. $]^{28}$

In this declaration, Vergara elucidates the complex question of guilt and responsibility in situations of violent repression, assigning blame to the author of the crime: a murderer is someone who commits a murder. This distinction functions well in Vergara's case, given that he declared himself innocent in the accusations of homicide brought against him and that motivated his detention. This, however, is not a conclusive reflection. On the contrary, it forces us to consider what, then, would be the charge and the corresponding verdict brought against Vergara or any other individual who held a similar role in the detention centers. Accomplice? Collaborator? Accessory to the crimes? The consideration of a possible response poses new questions in the specific case of the protagonist: How would the accusations brought against Vergara and his subsequent punishment be impacted by the fact that Vergara was underage and worked for the military during a dictatorship when his possible crimes were committed?

Vergara delves into these questions himself in a later sequence of the film, in which he consults a renowned human rights lawyer, Nelson Caucoto, about the possibility of receiving governmental compensation for the emotional injuries he suffered while working at the Simón Bolívar detention center. Vergara feels that he deserves to be compensated for having been an "involuntary actor" in the crimes that occurred at Simón Bolívar and for the oppressive character of his experience, which damaged his personal development at an age that typically defines one's place in society:

Fui utilizado, en el fondo, porque cuando ya vieron que ya prácticamente no servía... De hecho me prohibieron estudiar, no me dejaron terminar la enseñanza básica ni nada. Me las tuve que jugar muy duramente para poder terminar mis estudios. Me aplicaron muchas prohibiciones, por decirlo así, entonces, me sentía en el fondo, prácticamente, como un preso más.

[I was basically used because when they already saw that I was practically of no use ... In fact, they prohibited me from studying; they didn't let me finish even a basic level of education or anything. I had to work really hard in order to be able to finish my studies. They placed a lot of restrictions on me, so to speak, so I felt practically like another prisoner. $]^{29}$

\footnotetext{
${ }^{28}$ Said and de Certeau, El mocito.

${ }^{29} \mathrm{Ibid}$.
} 
In lieu of lending clarity to the issues surrounding the accusations against Vergara and an appropriate sentencing, this passage only poses more questions: Can victims exist among victimizers? Innocents among the guilty? And, perhaps most crucially, can the guilty be among those who are generally understood to be innocent? As we will see, the documentary suggests that between the unquestionable poles of victim and victimizer, innocent and guilty, there is an ample spectrum of various grades, shades, and even overlaps, all of which transcend a more binary division of civilians and military. This complexity belies a more profound one that is at the very core of the Armed Forces' existence in society - a group of citizens who possess a legitimate monopoly on arms, centralized violence, and missions that might affect the civilian population.

The filmmakers approach this complexity, and we do as well, through the final question that Caucoto asks Vergara during their meeting: “¿Cómo es que pudo soportar tanto siendo un joven?" ["How did you manage to bear so much as a teenager?"] $]^{30}$ In other words, how is it possible that a "normal" adolescent, without any apparent disorders or disruptions that might prevent him from functioning in society, became an accomplice to crimes so abhorrent that, years later, they continue to torment him and bring shame to his family? Intent on understanding this process, Said and de Certeau seek to uncover the man behind the mocito of the DINA, and through an exploration of his distinct characteristics, comprehend the circumstances that led him to the army, the conditions that possibly propelled him to remain in the middle of the inferno - and even after that to continue working for the CNI after he came of age - and the consequences that all of these events had upon the rest of his life.

Throughout the documentary, the filmmakers show Vergara as a man transformed by his experience in the DINA, but also as someone who maintains lingering attributes that connect him to the rest of the population, to those who did not take part in the army's violent crimes. Throughout the film, we see many facets of Vergara: a aggressive man who is attracted to weapons; an affectionate father who worries about his daughter; a believer who seeks relief through religious ceremonies; a solitary man, even in public spaces or at community events; a disturbed man who is willing to collaborate with the human rights cause; a hard, tough man; and a survivor. This comprehensive look at Vergara and the aspects of his personality that paint him as a "common" man are, however, potentially controversial.

Speaking to this point, in the section of his article titled "La humanización del cómplice"/ "The Accomplice's Humanization," Lazzara notes,

Cuando se intenta generar un punto de identificación entre Vergara y el espectador, presentándolo como un hombre común, se corre el riesgo de diluir responsabilidades. Los relatos naturalistas y deterministas no nos sirven para analizar casos como éste."

[“When trying to create a point of identification between Vergara and the viewer by presenting him as a common man, you run the risk of diluting responsibilities. Naturalistic and deterministic accounts do not help us analyze cases like this one.] $]^{31}$

In this analysis, I maintain, on the contrary, that Vergara's responsibility is firmly established through his memories of the exterminations that occurred at Simón Bolívar, which are both an indelible mark of his participation and a central part of the documentary. His humanization, therefore, forces us to reflect upon the circumstances and the social structures that push a "common man" to become involved in the extermination and mortification of so many others. Dictatorial proceedings of the magnitude seen in Chile do not come to fruition solely at the hands of repressive ideologues and the state's principal executioners, but also require the participation of many "common" men and women in distinct roles with varying degrees of responsibility. Considering Vergara to be an exceptional man (mentally disturbed, a monster), and thus capable of having been an accomplice to the state's violent acts of repression, provides an easy answer to the question of

\footnotetext{
${ }^{30}$ Ibid.

${ }^{31}$ Lazzara, El fenómeno Mocito, 104.
} 
how such horror was possible. This simple solution, however, is not satisfactory because it impedes productive reflection upon the final attainment of nunca más on both the individual and collective levels.

The documentary provides examples that offer a glimpse into the structures that allowed such horrors to take place. The protagonist's initial words situate him as a witness in relation to the crimes: "I saw them, but nothing else."32 This - combined with the empathy that Vergara later affirms having felt in the face of the victims' suffering and the fact that, despite these feelings, he continued to work at the extermination center - may indicate a transformation that, according to Ervin Stub, witnesses often suffer: "Bystanders also learn and change as a result of their own action - or inaction. Passivity in the face of others' suffering makes it difficult to remain in internal opposition to the perpetrators and to feel empathy for the victims." ${ }^{\prime 33}$ However, Vergara's case is not that of a simple witness. In the following quote, for example, he clearly contradicts himself regarding his status solely as a witness, thus undermining the veracity of that classification: "Even though I participated in assassinations, kidnappings, and all of that [...] I didn't participate." ${ }^{34}$ His initial form of participation, ambiguous in its peripheral nature to the crimes, echoes the discoveries made by Milgram in his experiments exploring situations that enabled common people to exhibit cruel behavior. One of the elements presented in these situations is what Bauman refers to as floating responsibility: ${ }^{35}$ an organizational structure in which every member transfers his individual responsibility to his superior, who can then transfer it to something intangible yet central to the group, such as its mission and doctrine. Vergara makes it clear that he was not ultimately responsible for the crimes: "in fact, if you look at the facts, I wasn't a murderer." ${ }^{36}$ Although his work allowed his superiors to carry out murder and torture, he did not give the orders nor did heexecute the crimes, thereby permitting him to avoid blame.

Another element akin to the repudiation of responsibility is the distance between the repressive actions carried out and the abhorrent final result. As Bauman observes about the conclusions made by Milgram, "it is psychologically easy to ignore responsibility when one is only an intermediate link in a chain of evil action but is far from the final consequences of the action." ${ }^{37}$ We can clearly see this distancing manifested in Vergara's case, given that his seemingly neutral work of cleaning, cooking, and watching over the prisoners actually facilitated the extermination center's day-today functioning. Knowing this allows us to extend our understanding of the focus of Said and de Certeau's documentary: the current system at work in today's post-dictatorship era is marked by a clear disconnect-one largely rooted in processes of compartmentalization, misinformation, and rationalization - between individual actions both in and outside of the workplace and the criminal repercussions of these actions in the lives of others.

Like the division of tasks performed by the gears of a machine or the many clues leading to a crime, routine and habit often transform one's work and its moral implications into an unquestionable - and unquestioned-act. ${ }^{38}$ As the documentary reveals, while Vergara's job at the extermination center began with relatively routine tasks, his level of involvement in the crimes steadily increased, ultimately leading to contact with the evidence itself - the bodies of the victims and his later work for the CNI. The steady escalation of Vergara's participation at Simón Bolívar parallels the mechanism of "sequentiality" that Bauman observes in Milgram's experiments, which he suggests is one of the factors that forces individuals into potential situations of collaboration. When an actor experiences a gradual increase in his involvement in tasks that enable a criminal act to take place, he is unable to stop or abandon the process without first evaluating what has already occurred: if the next step in the chain of tasks can be judged as morally questionable, it

\footnotetext{
${ }^{32}$ Said and de Certeau, El mocito.

${ }^{33}$ Ervin Staub, "The Psychology of Bystanders, Perpetrators, and Heroic Helpers," Understanding Genocide: The Social Psychology of the Holocaust 3 (2008), 305-306.

${ }^{34}$ Said and de Certeau, El mocito. Author's emphasis.

${ }^{35}$ Zygmunt Bauman, Modernity and Holocaust (Cambridge: Polity Press, 1989), 162.

${ }^{36}$ Said and de Certeau, El mocito.

${ }^{37}$ Bauman, Modernity and Holocaust, 161.

${ }^{38}$ Ibid., 165.
} 
is therefore possible that the prior task was also morally questionable in some way. "Smooth and imperceptible passages between the steps lure the actor into a trap; the trap is the impossibility of quitting without revising and rejecting the evaluation of one's own deeds as right or at least innocent." ${ }^{39}$ Furthermore, as an actor advances within the chain of command, he encounters increasing obstacles that limit his ability to stop participating in the crimes or distance himself from his tasks. This sensation of imprisonment appears in the film during Vergara's conversation with Caucoto, when he affirms that, while working at the extermination center, he felt "practically like another prisoner." Although the protagonist attributes this sensation to the restrictions that were placed upon him, his explanation begins with a different idea, one connected with the theme of gradualness ("I was basically used because when they already saw that I was practically of no use..."). ${ }^{40} \mathrm{He}$ abruptly interrupts this thought, however, perhaps precisely to allow for a moment of self-critique. With a tone of resentment, he suggests that, in contrast to what he expected, and what was likely due to his level of involvement, his superiors disposed of him when his skills no longer suited their needs.

The restrictions that Vergara mentions in his conversation with Caucoto effectively severed his relationship with the world beyond the extermination center, creating an atmosphere that allowed only minimal opportunities for independent thought: he lived at the center and was not allowed to attend classes or to continue with his studies. Accordingly, the military limited his ability to question the events he observed or experience a moral dilemma as a result of his collaboration. As Bauman affirms, "the readiness to act against one's own better judgment, and against the voice of one's conscience, is not just the function of authoritative command, but the result of exposure to a single-minded, unequivocal and monopolistic source of authority. ${ }^{41}$ This introduces a relevant reflection on the audience's present, regarding the value of authentic pluralism in society as a tool that encourages the use of critical judgment and helps curve the impulse to commit morally questionable acts.

In her essay "Personal Responsibility Under Dictatorship," Hannah Arendt enriches this reflection by suggesting that many average people who have collaborated in some way with oppressive regimes have not done so out of support for the regime's goals, but rather because they understand that the only way in which they can participate in society - and thus the regime - is through a demonstrated respect for the laws and norms that sustain it: they automatically substitute one value system for another, an old order for a new one. ${ }^{42}$ According to Arendt, this conduct directly opposes the act of thinking, that is, of questioning the dominant order: an act that stems from the need to live in peace with one's self and always provokes resistance. ${ }^{43}$ The rise of independent thought in sociopolitical systems (authoritarian or democratic) that in reality aspire to suppress thought-to encourage obedience and civilian support-is difficult to explain. For Arendt, " $\mathrm{t}]$ he dividing line between those who want to think and therefore have to judge by themselves, and those who do not, strikes across all social and cultural or educational differences." ${ }^{44}$ It could also be argued, however, that the reasons behind a lack of thought-or a lack of desire to engage in thought- change according to one's socioeconomic standing.

The documentary explores this possibility through an examination of social class. In one particular scene, Vergara gets together with his brother, Francisco Vergara, so that he can tell the protagonist's story from the perspective of a family member. His appearance and manner of

\footnotetext{
${ }^{39}$ Ibid., 159.

${ }^{40}$ Said and de Certeau, El mocito.

${ }^{41}$ Bauman, Modernity and the Holocaust, 166.

${ }^{42}$ Hannah Arendt, Responsabilidad y juicio (Barcelona: Ediciones Paidós, 2007), 69. Deleuze and Guattari's notion of "microfascism" is complementary to this reflection. According to their discussion, the problem does not lie in the type of rules that individuals must follow, but rather in the desire and the individual need to follow them and make others follow them; the desire of the same power that oppresses us. For futher elaboration, see Gilles Deleuze and Felix Guattari, A thousand plateaus: capitalism and schizophrenia, trans. Biran Massumi (Minneapolis: University of Minnesota Press, 1987), 214.

${ }^{43}$ Ibid., 71.

${ }^{44}$ Ibid., 45.
} 
speaking indicate both his rural, working class background and his lack of education, and his version of events highlights Vergara's roots in the same reality. Francisco justifies his brother's work in the DINA with his precarious economic situation, the ease with which he obtained the job, the indoctrination he suffered, and the transformation that he underwent as a result of his experience at the center.

Fue fácil para ellos ingresar a trabajar en el cuento ese que era la DINA. Los preparaban un poco nomás y vamos trabajando. Yo mismo si hubiera ido a Santiago capaz que me hubieran metido y hubiera terminado trabajando en la DINA o en la CNI. Pero no, no lo habría hecho. Jorgelino lo hizo más por necesidad, porque él se fue solo a Santiago. Y en la familia se toca muy poco el tema ese porque es como una vergüenza, ¿me entiende? [...] Porque a él lo prepararon para trabajar, como quien dice le hicieron un lavado de celebro (sic). Y después que salió de la DINA ya Jorgelino no es el mismo.

[It was easy for them to get a job in the business that was the DINA. They prepared them just a little bit, nothing more, and then they started working. If I had gone to Santiago it's possible that I would've gotten involved and ended up working for the DINA or the CNI. But no, I would've have done it. Jorgelino did it more than anything out of necessity, because he went to Santiago alone. And in our family we don't talk about this a lot because it's sort of an embarrassment, you know? [...] Because they prepared him to work, and as you might say, they brainwashed him. And after he left the DINA, Jorgelino wasn't the same anymore. ${ }^{45}$

The hint of agency that Francisco Vergara appears to introduce with respect to his brother's actions by noting, "I wouldn't have done it," disappears in the face of Vergara's need to survive and the vulnerability he felt being far from his family at such an early age. ${ }^{46}$ Vergara's transformation as a result of his interactions at the extermination center-his exposure to a self-legitimized monolithic authority, his superiors' normalization of cruelty, and his rapid integration into the group - further substantiates and explains his actions.

This apparent dilution of the protagonist's agency preoccupies Lazzara, who sees Vergara as someone who, although damaged, tried to benefit materially from Chile's repressive system. ${ }^{47}$ Although this may be true, to generate a broader understanding in this article, it is necessary to consider the social structures and conditions that drive an individual to feel, think, and act in such a manner. In his article, Lazzara suggests that subjects like Vergara, who lack power, culture, or familial support, are produced by certain economic and political structures and exploited by repressive systems. ${ }^{48}$ While I agree with this assertion, I am interested in digging deeper into the relationships that it establishes, given that the "certain economic and political structures" to which Lazzara refers pertain to periods of democracy. If during authoritarian regimes these formerly marginalized subjects are exploited by the repressive system, we must first look at the democratic society in which these subjects emerge, as well as the prevailing economic systems and their relationship to the army. If, as a result of its oppressive characteristics, the Chilean economic system continues to produce "mocitos," and the army continues to be a hierarchical and authoritarian institution with the space to impose its logic upon the population and attract the poorest members of society, then it is probable that, when faced with a new military coup, this type of individual would collaborate once again. Accordingly, this establishes a line of continuity between the dictatorship and democracy that requires our attention.

With respect to the relationship between the civilian government and the army, Marcela Said's first documentary, I Love Pinochet ${ }^{49}$, released in 2001, was revelatory. In an effort to depict the

\footnotetext{
${ }^{45}$ Said and de Certeau, El mocito.

${ }^{46}$ Ibid.

${ }^{47}$ Lazzara, El fenómeno Mocito, 98.

${ }^{48}$ Ibid., 104.

${ }^{49}$ Marcela Said, I love Pinochet (Santiago de Chile: Imago, 2002).
} 
phenomenon of pinochetismo, Said interviews families and individuals from distinct social classes and also visits the military academy. During the visit to the military academy, Said observes moments in class in which, under the guise of religion, the instructor openly defends the military dictatorship, degrades the democratic system as a producer of misery, exalts obedience as a synonym for total liberty, and praises military commitment that involves sacrifice for the homeland. Ten years later, as the documentary El soldado que no fue $e^{50}$ shows, the officials who were interviewed continue to proudly defend the vision of the army as the savior of society and a guarantor of order.

Other episodes in El mocito that occur both before and after the encounter with Vergara's brother add new insight into the socioeconomic dimension of the protagonist's actions. For example, we learn through the testimonies of the residents who live in the humble region of Chile where Vergara settled after leaving the army that, upon his arrival, he pretended to have a military command post and behaved in the same abusive manner as his superiors at the center: "pintando el mono de que, puta, él si quería hacía la cagada aquí en la población, que hacía lo que él quería y a que a él, puta, nadie le podía parar el avión, y que él no era cualquiera" ["he was making such a fool of himself, pretending that he could fuck shit up here in town if he wanted, that he could do whatever he wanted, and that nobody could clip his wings, and that he wasn't just anybody." ${ }^{51}$ Vergara's aspiration to be not just "anybody" emphasizes that his affiliation with the army gave him a sense of inclusion, validation, and status that is difficult to achieve in Chilean society, particularly for someone from a marginalized background. His impulse to use this affiliation and feign a higher status within the military corresponds to a need to separate himself from the poor population into which he saw himself forced to return.

The following quote confirms that the military's greatest source of superiority comes from the fear experienced by the civilian population after a prolonged period of unrestricted and unpunished power: "los policías en aquella época eran pesados, los policías de aquella época eran muy mala clase, pegaban y después decían por qué" ["the police back then were unpopular, the police at that time had a bad reputation, they would beat people first and then explain why." $]^{52}$ Before the dictatorship, the prestige of the Armed Forces was related both to its legitimate role as a political actor, as well as its composition, which was historically dominated by the middle class and the provincial upper class. ${ }^{53}$ By the 1960s, confronted with dwindling numbers, the army began to recruit members of the lower class, thereby minimizing the importance of socioeconomic standing; since then, however, there has been a clear resurgence of class-consciousness within the military and its institutions. In 2012, for example, the army issued an internal directive in which, as a security means, it recommended that the selection commission exclude "aquellos que presenten problemas de salud física, mental, socioeconómica, delictuales, consumidores de drogas, homosexuales, objetores de conciencia y testigos de Jehová" ["those who present problems with their physical and mental health, socioeconomic standing, delinquents, drug addicts, homosexuals, conscientious objectors, and Jehovah's Witnesses"] in order to recruit "ciudadanos más idóneos moral e intelectualmente capacitados" ["the most morally fit and intellectually capable individuals."] ${ }^{54}$

The centrality of Vergara's affiliation with the military in the construction of his identity continues to develop during his encounter with the head of the Lautaro Brigade, Juan Morales Salgado, who was brought to justice as a result of Vergara's testimony. During their conversation, Vergara notes: "Yo conozco muchas facetas de su persona Sr. Morales y lo respeto mucho [...] Fueron como mis padres en esa brigada y como madres también, las mujeres me querían mucho" [“I know many facets of your personality, Mr. Morales, and I respect you a lot [...] They were like

\footnotetext{
${ }^{50}$ Leopoldo Gutiérrez, El soldado que no fue (Santiago de Chile: Polo Comunications, 2010).

${ }^{51}$ Said and de Certeau, El mocito; author's emphasis.

${ }^{52}$ Ibid.

${ }^{53}$ Lisa North, "The Military in Chilean Politics," in Armies and Politics in Latin America, ed. Abraham F. Lowenthal and John Samuel Fitch (New York: Holmes \& Meier, 1986), 74-75.

54 "Escándalo por instructivo del Ejército que incita a la discriminación en el reclutamiento," Diario y Radio Uchile, September 7, 2012, accessed August 9, 2017, http://radio.uchile.cl/2012/09/07/escandalo-por-instructivo-del-ejercitoque-discrimina-a-homosexuales-personas-de-bajos-recursos-y-testigos-de-jehova/; author's emphasis.
} 
my fathers in that brigade and like mothers too, the women cared for me a lot." $]^{55}$ In this quote, the sense of validation that Vergara previously noted gains an affective dimension. This sense of affection, generated by his contact with the other members of the brigade, does not appear to conflict with the pain that Vergara felt upon witnessing their acts of repression ("they killed them so shamelessly that it hurt me as a teenager") or even his own oppression at their hands ("I felt like I was practically like another prisoner." $)^{56}$ This contradiction allows us to consider different explanations or interpretations.

On one hand, the importance of belonging becomes a reaffirming factor in situations of internal conflict. As Bauman observes, a victim's physical isolation necessarily implies a certain proximity to his victimizers: "Physical closeness and continuous co-operation tends to result in a group feeling, complete with the mutual obligations and solidarity it normally brings about." 57 We can observe this process in the film when Vergara mentions Morales' "many facets" and the parental roles fulfilled by his companions. In such cases, the intimacy fostered by the group setting allows new aspects of a person's character to emerge that extend beyond his role at work, thus further strengthening group members' bonds. Moreover, the fact that the perpetrator belongs to a group greatly facilitates his ability to enact violence, which, accordingly, begins to take on a collective character. ${ }^{58}$

On the other hand, it is possible that the profound contradictions expressed by Vergara are evidence of a survival mechanism, one that allowed him to adapt to a hostile environment and protect himself from being either physically or psychologically abused. As the film progresses, Vergara adds the term "survivor" to his initial description of himself as "a prisoner almost." ${ }^{99}$ In one particular scene, a drunk Vergara reaffirms his willingness to contribute to the human rights cause despite the consequences that it may bring, noting:

Yo se sobrevivir. Porque ese conocimiento me lo dieron quienes tenían que dármelo y lo he recopilado y sé sobrevivir y eso en el fondo me da fortaleza [...] ¿Tú crees que alguna vez en la vida yo me he quebrado por eso? Jamás. No me quiebro. ¿Sabes porque no me he quebrado? Porque me enseñaron, en la vida, a no quebrarme: a ser fuerte, a ser perro.

[I know how to survive. Because I got that knowledge from people who had to give it to me and I've gathered it up and now I know how to survive and that gives me strength deep down [...] You think that at any point in my life I've broken because of that? Never. I don't break. Do you know why I haven't broken? Because they taught me, in life, how to not break: to be strong, to be fearless. $]^{60}$

In this passage, the protagonist refers to a learning process that provided him with a specific knowledge, but fails to mention the lessons involved in it, perhaps because of their traumatic nature. If he indeed learned to survive and not break, it is because he experienced circumstances that he perceived as a threat to his physical and emotional integrity. In this context, an affective identification with his perpetrators could be the expression of a compromise that allowed his tormented psyche to continue functioning. ${ }^{61}$

\footnotetext{
${ }^{55}$ Said and de Certeau, El mocito.

${ }^{56}$ Ibid.

${ }^{57}$ Bauman, Modernity and Holocaust, 156.

${ }^{58}$ Ibid., 157.

${ }^{59}$ Said and de Certeau, El mocito.

${ }^{60}$ Said and de Certeau, El mocito.

${ }^{61}$ Other agents who worked in the Lautaro Brigade express similar contradictions, typical of traumatized individuals. Adriana Rivas, for example, Manuel Contreras' former secretary who now lives in Australia, has a similarly fragmented and incoherent discourse. On one hand, she defends torture as a method to obtain information. Yet, on the other hand, she asserts that she never attended a torture session and that she could not bear to see the torture of another human being. Although she defends the lack of information about the desaparecidos, she empathizes with their
} 
The notion of "adaptation," explored by Argentine sociologist and genocide expert Daniel Feierstein, contributes to our understanding of this phenomenon. As one of the principal goals of the concentration camp system, adaptation is a survival mechanism in which the victim, in the face of a total annihilation of his or her subjectivity after being tortured, comes to either partially or fully identify with the values of his or her perpetrators. ${ }^{62}$ While prisoners held at detention centers are the principal target of adaptation, its effects transcend prison walls and ultimately impact society at large - albeit in a diluted form - through an authoritarian sociopolitical climate, the testimonies of survivors, and the unknown knowledge of what happened, despite the visible marks of repression in the public sphere. ${ }^{63}$ Because Vergara occupied a position on the edges, residing both inside and outside of the military, it is possible that he experienced the process of adaptation more intensely than other civilian-witnesses. Moreover, the evident respect and affection that Vergara feels for those who, by his own account, committed merciless murders and actively oppressed him could also be related to class. Throughout the film, Vergara evidences a submissive and deferential attitude toward authority, characteristic of a devalued individual who lacks the social consciousness to recognize his own oppression and who is accustomed to obeying and depending upon others, particularly his superiors, in order to survive.

Finally, further reflection upon the kinship vocabulary used by Vergara to describe his relationships with other members of the brigade ("fathers" and "mothers") allows us to consider the role of military corporatism under a dictatorial regime. The common expression "military family" used by members of the army and their most intimate biological relations highlights an exclusive, powerful, and loyal system of interpersonal relationships within the military and its affiliated institutions. These tight bonds complicate possible dissidence and unfaithfulness during times of conflict with the civilian population, given that all members of the military, especially the army and its constituent groups, retain a connection with civilian life. As his brother notes in the film, it is perhaps this sense of exclusivity shared by members of the military that led Vergara to cut all ties with his family and acquaintances while working at the extermination center and the CNI.

The sequence of photographs shown after the interview with Morales highlights another aspect of the interconnection between Vergara's personal and professional lives. The photos show Vergara, dressed in his uniform and armed, strolling with his wife and daughter in different locations. Vergara assumes the roles of father and husband from within his place in the military, and it is this sense of belonging that allows him to occupy other roles typically associated with a respectable male adult. In his recent study, Leith Passmore observes that, even prior to Pinochet's regime, completing military training was, for many young men, one of the key experiences linked with their transition into manhood, along with working, getting married, and supporting a family. ${ }^{64}$ Masculinity, a quality exalted by the army, also defines personal worth and merits respect in other areas of Chile's patriarchal society. In the era of the coup d'état, many young people already possessed a stereotypical image of a soldier, based primarily upon American movies, as a strong, unyielding, brave, and a violent man. ${ }^{65}$ We can see these characteristics manifested at multiple junctures throughout the documentary: when Vergara trains at dawn using a nunchaku, when he hunts a rabbit with his bare hands, showing clear experience with the task, and when he visits a

mothers. Furthermore, while she is aware of the Lautaro Brigade's violent actions, she, nonetheless, defines her time in the DINA as the happiest years of her youth- Florencia Melgar, "El otro once de septiembre: Entrevista con Adriana Rivas," SBS en español, September 13, 2013, accessed March, 19 2018, https://www.sbs.com.au/yourlanguage/spanish/ es/audiotrack/other-911-interview-adriana-rivas?language=es.

${ }^{62}$ Daniel Feierstein, El genocidio como práctica social: entre el nazismo y la experiencia argentina: hacia un análisis del aniquilamiento como reorganizador de las relaciones sociales (Buenos Aires: Fondo de Cultura Economica, 2007), 371; For a study on the use of torture in Chile during the dictatorship and its effects upon prisoners, see "Técnicas de tortura aplicadas en Chile: su acción, sus objetivos, sus efectos," desaparecidos.org, 1982, accessed August 8, 2017, http://www. desaparecidos.org/nuncamas/web/investig/persona/person07.htm.

${ }^{63}$ Feierstein, El genocidio, 379.

${ }^{64}$ Leith Passmore, "The apolitics of memory: Remembering military service under Pinochet through and alongside transitional justice, truth, and reconciliation," Memory Studies 9, no. 2 (2016), 177.

${ }^{65}$ Ernesto Garratt and Rafael Valle, "Revista de Cine Mabuse," Sin novedad en el frente: el soldado americano en el cine, January 5, 2003, accessed August 9, 2017, http://www.mabuse.cl/historia.php?id=31404. 
street fair booth and demonstrates a strong familiarity with handling arms ${ }^{66}$ As Connell suggests in "Masculinities, violence, and peacemaking," a push toward guaranteeing peace within a nation cannot occur under an exchange of hegemonic masculine ideas extolled primarily by the army, "which emphasize violence, confrontation and domination." ${ }^{67}$

The scene in which Vergara hunts a rabbit (he collects the animal from a trap, wounded and screeching; he then breaks its neck, skins it, and cleans the body) reveals a disturbing coldness and sense of indifference in the face of suffering and death. At the same time, this particular moment of the film calls attention to the importance of method and precision in the practice of cruelty, a crucial detail when considering the mechanisms that allow such horrific acts to take place in torture centers. By applying a learned method with clearly delineated steps, the perpetrator can focus on each element of his task, rather than on the consequences, i.e. the torment that he is inflicting upon others. This method also validates the use of torture as a historical act, one previously designed and employed in similar situations. Because of the torturers' methodical approach to their work, Vergara is able to clearly describe the scene that he observed repeated on multiple occasions: the use of electrical shock on prisoners during their torture sessions. Furthermore, this faithfulness to method, even in his daily life, and the clear delimitation of his role at the extermination center, likely facilitated Vergara's relationship to the events that he witnessed as mere components of his job, ones lacking any moral, ethical, or political implications.

In fact, Salgado Morales, who brought Vergara from Manuel Contreras's house, where he worked, to his new job at the extermination center, remembers him as "muy trabajador" ["very hardworking." $]^{68}$ This description coincides once again with Bauman's observations on Milgram's experiment, particularly the notion of the moralization of technology, specific to authoritarian bureaucratic systems, in which there is a division of tasks and a clear chain of command. It also highlights how employees manage to avoid moral dilemmas, shifting judgment of their actions, such as their significance and consequences, to how they were carried out. In other words, they adjust themselves to the rules of the organization and the expectations of their supervisors, who proffer moral approbation to their subordinates through either approval or other forms of validation..$^{69}$ In Vergara's case, the description given to him by his boss at the extermination center - "very hardworking" - as a positive moral judgment implies his total submission to the center's rules and the demands of his work.

In conclusion, the unusual glimpse that $E l$ mocito offers of perpetrators in situations of statesponsored violence is an important contribution to Chile's collective memory for multiple reasons. First, by choosing to focus on a protagonist affiliated with the state's violent acts of repression, the film emphasizes the significant amount of work that remains to be done on human rights abuses in Chile. After its initial presentation of Vergara, the documentary offers the following statistics: "A la fecha, la justicia chilena ha condenado a 260 agentes, de los cuales 51 cumplen pena efectiva" ["Since the fall of Pinochet's regime, the Chilean justice system has condemned 260 agents, 51 of whom are currently serving their sentences." $]^{70}$ In an interview following the film's release, Said notes that these 260 agents formed part of a significantly larger group, estimated at between 3,000 and 5,000 agents, who worked for the DINA/CNI. Based on these facts, the filmmaker concludes that Chile, "está haciendo justicia a duras penas" ["is hardly bringing about justice"], and affirms that $\mathrm{El} \mathrm{mocito,} \mathrm{as} \mathrm{a} \mathrm{film} \mathrm{focused} \mathrm{on} \mathrm{the} \mathrm{figure} \mathrm{of} \mathrm{the} \mathrm{repressor,} \mathrm{presents} \mathrm{an} \mathrm{opportunity} \mathrm{for} \mathrm{"la}$ sociedad se confronte con su pasado" ["society to confront its past."] $]^{71}$

Second, El mocito allows us to reflect upon the structures, situations, and interactions that bring common, morally adjusted individuals to support a repressive system rooted in the harassment and

\footnotetext{
${ }^{66}$ Said and de Certeau, El mocito.

${ }^{67}$ Bob Connell, “Masculinities, Violence, and Peacemaking,” Peace News 2443 (2001), 14-16, accessed August 8, 2017, https:/peacenews.info/node/3613/masculinities-violence-and-peacemaking.

${ }^{68}$ Said and de Certeau, El mocito.

${ }^{69}$ Bauman, Modernity and Holocaust, 161.

${ }^{70}$ Said and de Certeau, El mocito.

${ }^{71}$ Eva Usi, “'El mocito' estremece en la Berlinale,” DW Made for Minds, February 18, 2011, accessed August 9, 2017, http:// www.dw.com/es/el-mocito-estremece-en-la-berlinale/a-6442761.
} 
annihilation of others. This chance to reflect allows us to identify settings, both inside and outside of repressive systems, that facilitates the enactment of cruelty, thereby opening a space in which we can potentially resist these systems and imagine possible alternatives. Floating responsibility, the compartmentalization of tasks, distancing actions and their consequences, weakening pluralism, and establishing affiliations in opposition to others are some of the constituent mechanisms of these repressive systems that have extended to other areas of civil society and subsequently become normalized. Accordingly, the connection between the protagonist's socioeconomic situation and his later participation in state-mandated repression invites us to reconsider continuations of the dictatorship into present day, as well as the role of civil-military relations in a democratic era.

Finally, the question of the Armed Forces - an organization that continues to play a central role in the production of cruelty due in large part to its hierarchical, authoritarian, and violent character, but also maintains autonomy, special privileges, and influence upon Chilean society (including its role in the construction of a dominant masculine subjectivity)-underlies the entire documentary and functions as a warning directed in particular at Chile's political class and the country's civilian population as a whole. It is a warning directed at the political class because they maintain certain authoritarian enclaves in order to avoid confronting growing social problems that lack simple solutions: the need for justice without exceptions, the increasing protests highlighting social inequality, the poverty plaguing a significant portion of the population, and the marginal position of Chile's native populations. It is a warning to the civil society as possible collaborators and accomplices of situations leading to human rights violations in the new democratic era.

\section{Acknowledgements}

This article was translated into English by Edith J. Adams.

\section{Bibliography}

Aguero, Felipe. “Treinta años después. La ciencia política y las relaciones Fuerzas Armadas, Estado y Sociedad." Revista de Cienca Política 23, no 2 (2003), 251-272. Accessed December 21, 2017. http://www.scielo.cl/pdf/revcipol/v23n2/art13.pdf.

Álvarez Veloso, David. "Fuerzas Armadas en Chile: entre la configuración de nuevos roles y la normalización de las relaciones cívico-militares." Red de Bibliotecas Virtuales de Ciencias Sociales de América Latina y el Caribe. 2003. Accessed December 21, 2017. http://bibliotecavirtual.clacso.org.ar/ar/libros/becas/2003/mili/alvarez.pdf.

Arendt, Hannah and Jerome Kohn. Responsabilidad y juicio. Barcelona: Ediciones Paidós, 2007. Bauman, Zygmunt. Modernity and Holocaust. Cambridge: Polity Press, 1989.

"Colegios premilitares en Chile: El rigor de la disciplina." 24Horas.cl, May 25, 2015. Accessed December 21，2017. http://www.24horas.cl/nacional/colegios-premilitares-en-chile-elrigor-de-la-disciplina-1671628.

"Comité Contra la Tortura ONU regresó para revisar comrpomisos y avances." Enlace Mapuche Internacional Noticias, April 4, 2016. Accessed August 8, 2017. http://www.mapuche-nation. org/espanol/html/noticias/ntcs-562.html.

Connell, Bob. "Masculinities, Violence, and Peacemaking." Peace News 2443, (2001), 14-16. Accessed August 8, 2017. https://peacenews.info/node/3613/masculinities-violence-and-peacemaking.

Contreras, Dan. "La violencia, el servicio military y el sistema educativo en Chile." War Resisters International, May 17, 2014. Accessed August 8, 2017. http://www.wri-irg.org/en/ node/23364.

Deleuze, Gilles and Félix Guattari. A Thousand Plateaus: Capitalism and Schizophrenia. Minneapolis: University of Minnesota Press, 1987.

EFE. "Adriana Rivas, ex agente de la DINA defiende la tortura." Publimetro. September 13, 2013. Accessed August 8, 2017. https://publimetro.cl/cl/nacional/2013/09/13/adriana-rivasexagente-dina-defiende-tortura.html.

"Escándalo por instructivo del Ejército que incita a la discriminación en el reclutamiento." Radiochile. cl, September 7, 2012. Accessed August 8, 2017, http://radio.uchile.cl/2012/09/07/escandalopor-instructivo-del-ejercito-que-discrimina-a-homosexuales-personas-de-bajos-recursosy-testigos-de-jehova/. 
Feierstein, Daniel. El genocidio como práctica social: entre el nazismo y la experiencia argentina: hacia un análisis del aniquilamiento como reorganizador de las relaciones sociales. Buenos Aires: Fondo de Cultura Economica, 2007.

Florina Matei, Cristiana and Marcos Robledo. "Democratic Civilan Control and Military Effectiveness in Chile." In The Routledge Handbook of Civic-Military Relations. Edited by Florina Cristiana Matei and Thomas Bruneau. New York: Routledge, 2013.

Garratt, Ernesto and Rafael Valle. "Sin novedad en el frente: el soldado 'americano' en el cine." Revista de Cine Mabuse, January 1, 2003. Accessed August 8, 2017. http://www.mabuse.cl/ historia.php?id=31404.

Gutiérrez, Camila. "El mocito del Mamo Contreras." The Clinic Online, June 23, 2011. Accessed December 22, 2017. http://www.theclinic.cl/2011/06/23/el-mocito-del-mamo-contreras/.

Gutiérrez, Leopoldo. El soldado que no fue. Santiago de Chile: Polo Comunications, 2010.

Guzmán, Nancy. Romo, confesiones de un torturador. Santiago: Editorial Planeta Chilena, 2000.

Iribarren, Mateo. El Tío. Santiago de Chile: Monkey Puzzle Media, 2013. DVD.

Larrazaba, Olga. "Líbranos de todo mal, amen." PiensaChile. Accessed December 22, 2017. http://piensachile.com/2011/11/libranos-de-todo-mal-amen-resena-de-la-pelicula-elmocito-de-marcela-said/.

Lazzara, Michael. "Complicity and Responsibility in the Aftermath of the Pinochet Regime: The Case of El Mocito." Rúbrica Contemporánea 5, no. 9 (2016), 60-76.

- "El fenómeno Mocito (Las puestas en escena de un sujeto cómplice)." A Contracorriente. Una revista de historia social y literatura de América Latina 12, no. 1 (2014), 89-106. Accessed August 8, 2017. https://acontracorriente.chass.ncsu.edu/index.php/acontracorriente/ article/view/1301.

Manríquez, Lorena and Miguel Picker. La odisea de Ulises. Los Angeles: Andes Media LLC, 2014. DVD.

Molina, Paula. "Los problemas de Chile y su ley antiterrorista." BBC Mundo, August 1, 2014. Accessed August 8, 2017. http://www.bbc.com/mundo/noticias/2014/08/140801 chile ley antiterrorista nc.

Mayoraga, René Antonio. “Las perspectivas de consolidación de la democracia y los problemas de las relaciones institucionales cívico-militares." In La cuestión militar en cuestión. Democracia y Fuerzas Armadas, edited by Raúl Barrios Morón and Rene Antonio Mayoraga, 47-61. La Paz: Centro Boliviano de Estudios Interdisciplinarios, 1994.

Melgar, Florencia. "El otro once de septiembre: Entrevista con Adriana Rivas. SBS en español. September 13, 2013. Accessed March 19 2018. https://www.sbs.com.au/yourlanguage/ spanish/es/audiotrack/other-911-interview-adriana-rivas?language=es.

Morales, Jorge. "El mocito. La trampa narcisita." Revista de cine Mabuse. Accessed December 22, 2017. http://www.mabuse.cl/critica.php?id=86530.

North, Liisa. "The Military in Chilean Politics." In Armies and Politics in Latin America, edited by Abraham Lowenthal and Samuel J. Fitch. 167-198. New York: Holmes and Meier Publishers, 1986.

Parra, José Z. "El mocito. Amargas verdades." La fuga. Revista de cine. no. 13 (2012). Accessed December 21, 2017. http://www.lafuga.cl/el-mocito/492.

Passmore, Leith. "The apolitics of memory: Remembering military service under Pinochet through and alongside transitional justice, truth, and reconciliation." Memory Studies 9, no. 2 (2016), 173-186.

"Privilegios para militares presos mantienen impunidad en Chile." Sputnik News, April 08, 2015. Accessed August 8, 2017. http://mundo.sputniknews.com/opinion/20150804/1039956389. html.

Quaretti, Lucía. “El mocito." Revista Cine Documental. no. 6 (2012). Accessed December 22, 2017. http://revista.cinedocumental.com.ar/6/criticas 06.html.

Rebolledo, Javier. La danza de los cuervos: el destino final de los detenidos desaparecidos. Santiago de Chile: Ceibo Ediciones, 2012.

Rebolledo, Javier, and Dauno Tótoro Taulis. A la sombra de los cuervos: los cómplices civiles de la dictadura. Santiago: Ceibo Ediciones, 2015. 
Rodríguez Torres, Gonzalo. “Los otros abuelos osos sobrevivientes de la dictadura pero olvidados e invisibilizados en democracia." Radio Villa Francia. Levantando la Voz, March 16, 2016. Accessed August 8, 2017. http://www.radiovillafrancia.cl/los-otros-abuelos-osossobrevivientes-de-la-dictadura-pero-olvidados-e-invisibilizados-en-democracia.

Ros, Ana. "Los otros con armas: Las complejas relaciones cívico militares en el Chile de posdictadura." A Contracorriente. Revista de historia social y literatura de América Latina. 14, no. 2 (2017), 17-42. https://acontracorriente.chass.ncsu.edu/index.php/acontracorriente/ article/view/1560.

Said Cares, Marcela. I love Pinochet. Santiago de Chile: Imago, 2002.

Said, Marcela and Jean de Certau. El mocito. Santiago de Chile: Icalmafilms, 2011. DVD.

Serra, Narcís. The Military Transition: Democratic Reform of the Armed Forces. New York: Cambridge University Press, 2010.

Staub, Ervin. "The Psychology of Bystanders, Perpetrators and Heroic Helpers." Understanding Genocide: The Social Psychology of the Holocaust 3 (2008), 4-32.

Stern, Steve. Reckoning with Pinochet. Durham \& London: Duke University Press, 2010.

"Técnicas de tortura aplicadas en Chile: su acción, sus objetivos, sus efectos." desaparecidos.org. 1982. Accessed August 8, 2017. http://www.desaparecidos.org/nuncamas/web/investig/ persona/person07.htm.

Usi, Eva. “El mocito estremece en la Berlinale." DW Made for minds. July 14, 2011. Accessed August 8, 2017. http://www.dw.com/es/el-mocito-estremece-en-la-berlinale/a-6442761.

Verdugo, Patricia. Caso Arellano: Los zarpazos del puma. Santiago: CESOC Ediciones, 1989. . Pruebas a la vista: La caravana de la muerte. Santiago: Sudamericana Chilena, 2000.

Verdugo, Patricia and Sebastian Brett. De la tortura no se habla: Agüero versus Meneses. Santiago: Catalonia, 2004.

Villalobos, Jara. "El mocito de Marcela Said y Jean De Certau." El blog de Villalobos Jara. November 24, 2011. Accessed December 22, 2017. https://villalobosjara.wordpress.com/page/21. 